\title{
Formulation and Evaluation of Taste Masked Fast Disintegrating Tablet of Promethazine Hydrochloride
}

\author{
Smita Kolhe* ${ }^{1}$, Tejashree Ghadge ${ }^{1}$, Dr.S.N.Dhole1 \\ Modern College of Pharmacy (For Ladies),Moshi, Borhadewadi,Pimpri,Pune(MS),India
}

\begin{abstract}
:
Purpose: To mask the bitter taste of the widely used antiallegic drug, Promethazine Hydrochloride(PMZ HCL), and to formulate it into patient-compliant and convenient fast disintegrating tablets.
\end{abstract}

Methods: Taste masking of Promethazine Hydrochloride was achieved by microencapsulation using amino alkyl methacrylate copolymers (Eudragit E100) employing the solvent evaporation technique. Taste assessment was carried out by time intensity metod. Sublimation method was used, using camphor as subliming agent, sodium starch glycolate and crosspovidone as a super-disintegrant was used to prepare fast disintegrating tablets. Tablets were evaluated with regard to a variety of pharmacopoeial tests, drug release, and disintegration time in the oral cavity.

Results: The time intensity method confirmed tasteless nature of the optimized microspheres. In vitro dissolution studies at pH 6.8 showed that no significant amount of drug is released while tablet is in mouth and approximately $92.3 \%$ of the release takes place in $15 \mathrm{~min}$ at gastric $\mathrm{pH}$ of $0.1 \mathrm{~N} \mathrm{HCl}$ indicating that tastemasking the drug with the $\mathrm{pH}$-sensitive polymer does not affect the release of the drug in the stomach.

Conclusions: Sensory evaluation for taste by a time inetensity method on 6 healthy volunteers confirms the successful formulation of the oral palatable fast disintegrating tablets which disintegrates in the oral cavity in $15 \pm 0.4 \mathrm{~s}$.

KEYWORDS: Eudragit E100, Fast disintegrating tablets, Superdisintegrant, Taste masking, Promethazine Hydrochloride.

\section{INTRODUCTION}

Fast disintegrating tablets (FDTs) have received increasing attention during the last decade, and the field has become a rapidly growing area in the pharmaceutical industry. Upon introduction into the mouth, these tablets dissolve or disintegrate in the absence of additional water allowing the easy administration of active pharmaceutical ingredients [1]. Such dosage forms are useful and convenient for children, older persons, and others who are unable to swallow conventional tablets and capsules. Masking the unpleasant taste of therapeutic agents is an important consideration in the formulation of FDTs and it can be achieved by minimizing direct contact between the active species and the taste receptors in the buccal cavity of the patient [2]. The unpleasant taste of the active drug can also be overcome by adding flavoring ingredients and sweeteners to improve taste and palatability. However, where the active drug possesses a particularly strong or bitter taste, such as is the case with many antibiotics, the mere addition of such flavoring ingredients and sweeteners is insufficient to improve taste and palatability. Accordingly, various taste-masked coating compositions have been used in the formulation of liquid suspensions and fast disintegrating tablet dosage forms [3]. Promethazine Hydrochloride is a antiallergic,anthistaminic agent. It is extremely bitter and, as yet, there is no commercially available mouth dissolving/ disintegrating taste-masked preparation that might be useful for geriatric or pediatric patients and others who cannot swallow tablets/capsules easily. Therefore, in the present study, an attempt has been made to mask its bitter taste and to formulate it into more accessible and patientcompliant fast-disintegrating tablets. Taste masking was achieved using the $\mathrm{pH}$ sensitive polymer Eudragit E100 [4]. Eudragit E100 is a cationic polymer based on dimethylaminoethyl methacrylate and other neutral methacrylic acid esters. It is soluble in gastric fluids as well as in weakly acidic buffer solutions up to $\mathrm{pH} 5$ but insoluble at salivary $\mathrm{pH}$ [5]. The sublimation method technique was used for preparing the FDTs since this process allows high productivity at a low cost.

\subsection{Materials}

\section{MATERIALS AND METHOD OF PREPARATION}

Promethazine Hydrochloride drug was a gift sample from Itaka pharmaceuticals Pvt Ltd, Eudragit E 100 was obtained as gift sample from Degussa India Pvt Ltd. Sodium starch glycolate, crosspovidone supplied 
by Maple biotech Pvt Ltd. All other chemicals and solvents used were of analytical grade. Paddle stirrer, dissolution apparatus, and UV-visible spectrophotomter were the equipments used in this study.

\subsection{Methods}

\section{Preparation of taste masked microspheres}

Microspheres were prepared by the solvent evaporation technique with necessary modifications Accurately weighed but varying amounts of Eudragit E100 were dissolved in $10 \mathrm{ml}$ of acetone over a magnetic stirrer and $500 \mathrm{mg}$ of accurately weighed promethazine hydrochloride was added to the polymer solution. Then, $50 \mathrm{mg}$ magnesium stearate was added to the solution of polymer and drug in acetone. Magnesium stearate was used as droplet stabilizer The organic phase was added drop-wise to $25 \mathrm{ml}$ of a 1: 1 mixture of light liquid paraffin and Petroleum ether containig span 80, (span 80 prevent aggregation between microsphere) with vigorous stirring using a mechanical stirrer. High stirring rates of approximately $1000 \mathrm{r} / \mathrm{min}$ were employed to obtain microspheres of smaller size. Stirring was continued for $1 \mathrm{~h}$. The batch was filtered and washed three times with $10 \mathrm{ml}$ hexane to remove any adhering liquid paraffin from the surface of the microspheres. This was followed by drying of the microspheres overnight at room temperature. Several batches of microspheres were prepared by varying the drug-polymer ratio, keeping all other formulation factors constant [6]. The drug polymer ratio taken was $1: 1,1: 2,1: 3,1: 4$.

\section{Preparation of FDTs of taste masked microsphere [7]}

The superdisintegrants (Kollidon-CL, Sodium starch glycolate) in varying concentration (4\%, 6\%, $8 \%$ $\& 10 \%$ ) used to develop the tablets. In this study fast-disintegrating tablet were prepared by using, taste masked drug, camphor as sublimating agent, mannitol as a diluent. All the ingredients were passed through \# 40 mesh separately. The taste masked drug and the diluents was mixed in small portion of both each time and blending it to get uniform mixture and set aside. The other ingredients were weighed and mixed in geometrical order, mixed thoroughly with lubricant. The tablet of weight $150 \mathrm{mg}$ were prepared by direct compression technique using $7 \mathrm{~mm}$ punch. After that compressed tablet were dried for $5 \mathrm{hrs}$ in oven for sublimation of camphor.

Table no. 1 Composition of all the batch of taste masked FDTs of promethazine hydrochloride

\begin{tabular}{|c|c|c|c|c|c|c|c|c|}
\hline $\begin{array}{c}\text { Formulation } \\
\text { ingredients }\end{array}$ & $\mathbf{F}_{\mathbf{1}} \mathbf{m g}$ & $\mathbf{F}_{\mathbf{2}} \mathbf{m g}$ & $\mathbf{F}_{\mathbf{3}} \mathbf{m g}$ & $\mathbf{F}_{\mathbf{4}} \mathbf{m g}$ & $\mathbf{F}_{\mathbf{5}} \mathbf{m g}$ & $\mathbf{F}_{\mathbf{6}} \mathbf{m g}$ & $\mathbf{F}_{\mathbf{7}} \mathbf{m g}$ & $\mathbf{F}_{\mathbf{8}} \mathbf{m g}$ \\
\hline $\begin{array}{c}\text { Microsphere } \\
\text { equivalent to 25mg }\end{array}$ & 100 & 100 & 100 & 100 & 100 & 100 & 100 & 100 \\
\hline Camphor & 10 & 10 & 10 & 10 & 10 & 10 & 10 & 10 \\
\hline crosspovidone & 4 & 6 & 8 & 10 & & & & \\
\hline $\begin{array}{c}\text { Sodium starch } \\
\text { glycolate }\end{array}$ & & & & & 4 & 6 & 8 & 10 \\
\hline Mannitol & 36 & 34 & 32 & 30 & 36 & 34 & 32 & 30 \\
\hline Talc & 1 & 1 & 1 & 1 & 1 & 1 & 1 & 1 \\
\hline Magnesium sterrate. & 1 & 1 & 1 & 1 & 1 & 1 & 1 & 1 \\
\hline
\end{tabular}

\subsection{Drug excipient compatability studied by FT-IR}

\section{EVALUATION PARAMETERS}

Compatbility of the drug with excipients was determined by FT-IR spectral analysis, this study was carried out to detect any changes on chemical constitution of the drug after combined it with the excipients. The samples were taken for FT-IR study.

\subsection{Diferential scanning colorimetry study}

Differential scanning calorimetry (DSC) thermograms of Pure drug, drug+polymer mixture samples were obtained using Differential Scanning Calorimeter (Jape, Perkin Elmer, USA). Samples (10 mg) were accurately weighed, hermetically sealed in an aluminum pan, and heated at a constant rate of $5^{\circ} \mathrm{C} / \mathrm{min}$ over a temperature range of $35^{\circ} \mathrm{C}$ to $400^{\circ} \mathrm{C}$.

\subsection{X- ray Powder Diffractometry study}

The X-ray powder diffraction patterns of selected samples were obtained using $\mathrm{X}$ - ray powder diffractometer (Bruker Axs Company). The radiation source was a copper ( $<$ lambda $>=1.54184$ A) highintensity X-ray tube operated at $35 \mathrm{kV}$ and $15 \mathrm{~mA}$. 


\subsection{Evaluation of microsphere $[8,9,10,11]$}

3.4.1 Bulk density $\left(D_{b}\right)$

The bulk density of powder is dependent on particle packing and changes as the powder consolidate. A consolidated powder is likely to have greater arch strength than a less consolidated one and may be therefore be more resistant to powder flow. The ease with which a powder consolidates can be used as an indirect method of quantifying powder. Apparent bulk density $(\mathrm{gm} / \mathrm{ml})$ is determined by pouring bulk powder into a graduated cylinder via a large funnel and measuring the volume and weight. Bulk density can be calculated by the following formula,

Bulk density: - $\mathrm{M} / \mathrm{V}_{\mathrm{b}}$

Where, $M=$ mass of the powder

$\mathrm{V}_{\mathrm{b}=}$ bulk volume of the powder

\subsubsection{Tapped density $\left(D_{t}\right)$}

Tapped density is the bulk density of powder which has been compacted by tapping or vibration.Tapped density was determined by placing a graduated cylinder containing a known mass of powder on mechanical tapping apparatus, which is operated for a fixed number of taps (100) or until the powder bed volume has reached a minimum. The tapped density is computed by taking the weight of power in cylinder and final volume.

Tapped density: - $\mathrm{D}_{\mathrm{t}=\mathrm{M}} / \mathrm{V}_{\mathrm{t}}$

Where, $M=$ mass of powder

$\mathrm{V}_{\mathrm{t}}=$ bulk volume of the powder

\subsubsection{Angle of repose ( $\theta)$}

The fractional force in a loose powder can be measured by the angle of repose ( $\theta)$. It is an indicative of the flow properties of the powder. It is defined as a maximum angle possible between the surface of the pile of powder and the horizontal plane. The powder mixture was allowed to flow through the funnel fixed to a stand at definite height (h). The angle of repose was then calculate by measuring the height and radius of the heap of powder formed. Care was taken to see that the powder particles slip and roll over each other through the sides of the funnel. Relationship between angle of repose and powder flow property.

$\operatorname{Tan}(\Theta)=\mathrm{h} / \mathrm{r}$

$\Theta=\tan ^{-1}(\mathrm{~h} / \mathrm{r})$

Where, $\theta$ is th angle of repose, $\mathrm{h}$ is the height in $\mathrm{cm}, \mathrm{r}$ is radius in $\mathrm{cm}$

Table no. 2 Angle of repose as an indication of powder flow properties

\begin{tabular}{|c|l|l|}
\hline Sr No & Angle of Repose & Type of flow \\
\hline 1 & $<20$ & excellent \\
\hline 2 & $20-30$ & Good \\
\hline 3 & $30-34$ & passable \\
\hline 4 & $>34$ & Very poor \\
\hline
\end{tabular}

\subsubsection{Carrs index (or) \% Compressibility}

Another indirect method of measuring powder flow from bulk densities was developed by carr. The percentage compressibility of a powder is a direct measure of the potential powder arch or bridge strength and stability. It is calculated according to the following equation,

Carr's index $(\%)=\left(D_{t}-D_{b} / D_{t}\right) \times 100$

Where $D_{t}=$ tapped density of the powder

$D_{b}=$ bulk density of the powder

Table no. 3 Relatioship between \% compressibility and flowability

\begin{tabular}{|c|l|l|}
\hline Sr No & \% Compressibility & Flowability \\
\hline 1 & $5-12$ & Excellent \\
\hline 2 & $12-16$ & Good \\
\hline 3 & $18-21$ & Fair Passable \\
\hline 4 & $23-35$ & Poor \\
\hline 5 & $33-38$ & Very poor \\
\hline 6 & $<40$ & Very very poor \\
\hline
\end{tabular}




\subsubsection{Hausners ratio}

Hausners ratio is indirect index of ease of powder flow. If the hausner ratio of powder is near to 1.25 , indicate better powder flow. It is calculate by the following formula,

Hausner ratio $=\mathrm{D}_{\mathrm{b}} / \mathrm{D}_{\mathrm{t}}$

Where, $D_{t}=$ tapped density of the powder

$D_{b}=$ bulk density of the powder

\subsubsection{Particle size}

The size distribution and average size of the microspheres were determined by sieve analysis using a set of 12 sieves ranging in size from $1.18 \mathrm{~mm}$ (\# 16) to 75 microns (\# 200) mounted on a sieve shaker unit was used. Amount of microspheres remaining on each sieve was then weighed and particle size was determined using optical microscopy. Optical microscope was fitted with eye piece micrometer which was then calibrated with a stage micrometer. Size of about 100 microspheres was calculated from each batch and then the average size was calculated.

\subsubsection{Morphology}

The morphology of the prepared batches of microspheres was evaluated by scanning electron microscopy (Hitachi S-520). Samples were mounted on aluminium stubs and coated with platinium using a vacuum evaporator. Samples were then examined with a SEM microscope.

\subsubsection{Entrapment efficiency}

A small quantity of microspheres was crushed in a glass mortar and to $10 \mathrm{mg}$ of an accurately weighed sample of this powdered mass, was added to $\mathrm{pH} 6.8$ phosphate buffer and analyzed spectrophotometrically at $\lambda \max 249 \mathrm{~nm}$ using buffer as blank. The entrapment efficiency of various samples was calculated using the following equation,

$$
\begin{aligned}
& \text { Entrapment }=\quad \text { Weight of incorporated drug }(\mathrm{mg}) \quad \mathrm{x} 100 \\
& \text { efficency Weight of drug used for microsphere preparation }(\mathrm{mg})
\end{aligned}
$$

\subsubsection{In-vivo taste evaluation of microspheres}

The prepared microspheres were subjected to taste evaluation test in 6 healthy male volunteers using the time intensity method. All the volunteers were given details about the purpose, any risk involved and the procedure for taste evaluation. Taste evaluation of PMZ HCL microspheres was conducted and the degree of bitterness was judged at several time interval for $15 \mathrm{~min}$ according to bitterness intensity scale from $0-3$ where 0 , $0.5,1,2,3$ indicate no, threshold, slight, moderate, and strong bitterness respectively.

\subsection{Evaluation of FDTs $[12,13,14,15]$ \\ 3.5.1 General appearance}

The general appearance of a tablet, its visual identity and over all "elegance" is essential for consumer accepatance. Include in are tablet's size, shape, colour, presence or absence of an odour, taste, surface texture, physical flaws and consistency and legibility of any identifying marking.

\subsubsection{Size and shape}

The size and shape of the tablet can be dimensionally described, monitored and controlled.

\subsubsection{Tablet thickness}

Tablet thickness is an important characteristic in reproducing appearance and also in counting by using Filing equipment Some filling equipment utilizes the uniform thickness of the tablets as a counting mechanism. Ten tablets were taken and their thickness was recorded using micrometer.

\subsubsection{Uniformity of weight}

I.P. Procedure for uniformity of weight was follow, twenty tablets were taken and their weight was determined individually and collectively on digital weighing balance. The average weight of one tablet was determined from the collective weight. The limit for weight variation is given in table no. 4 
Formulation And Evaluation Of Taste Masked...

Table no. 4 I.P. Limit for weight variation

\begin{tabular}{|c|c|c|}
\hline Sr no & Average weight of tablets(mg) & \% deviation \\
\hline 1 & $80 \mathrm{mg}$ or less & 10.0 \\
\hline 2 & More than $80 \mathrm{mg}$ but less than $250 \mathrm{mg}$ & 7.5 \\
\hline 3 & $250 \mathrm{mg}$ or more & 5.0 \\
\hline
\end{tabular}

\subsubsection{Tablet hardness}

Hardness of tablet is defined as the force applied across the diameter of the tablet in the order to break the tablet. The resistance of the tablet to chipping, abrasion or breakage under condition of storage transformation and handling before usage depends on its hardness. Hardness of the tablet of each formulation was determined using Monsanto Hardness tester.

\subsubsection{Friability}

It is measured of mechanical strength of tablets. electrolab friabilator (USP) EF-2 was used to determine the friability by following procedure. A preweighed tablet was placed in fribilator. Friabilator consist of plastic chamber that revolves at $25 \mathrm{rpm}$, dropping those tablets at a distance of 6 inches with each revolution. The tablets were rotated in the friabilator for at least 4 minutes. At the end of the test tablets were dusted and weighed, the loss in the weight is the measure of the friability and is expressed in percentage as,

$$
\% \text { Friability = initial-final/initial } \times 100
$$

\subsubsection{Wetting time}

Five circular tissue paper of $10 \mathrm{~cm}$ diameter are placed in petridish $10 \mathrm{ml}$ of water was poured into tissue paper placed in petridish. Tablet is carefully placed on surface of tissue paper. Time required for water to reach the surface of tablet is noted as wetting time.

\subsubsection{In vitro dispersion time}

Tablet was added to $10 \mathrm{ml}$ of phosphate buffer solution $\mathrm{pH} 6.8$ at $37+0.5^{\circ} \mathrm{C}$. Time required for complete dispersion of a tablet was measured.

\subsubsection{Disintegration test}

The test was carried out on 6 tablets using the apparatus specified in I.P. $2010900 \mathrm{ml}$ distilled water at $37^{\circ} \mathrm{C} \pm 2^{\circ} \mathrm{C}$ was used as a disintegration media and the time in second taken from complete disintegration of the tablet with no palpable mass remaining in the apparatus was measure in seconds.

\subsubsection{Dissolution studies}

In Vitro release studies of all formulation were performed according to U.S.P apparatus 2 paddle method maintained at $100 \mathrm{rpm}$ and $900 \mathrm{ml}$ dissolution medium. Sample $(5 \mathrm{ml})$ were collected at predetermined time interval and replaced with equal volume of fresh medium, filtered through a whatman filter paper and analysed with UV- Visible spectrophotometer (Shimadzu UV 1800) at $\lambda=249 \mathrm{~nm}$. Drug concentration was calculated from a standard calibration plot and expressed as cumulative $\%$ drug release. The release studies were performed in replicate of three. The in -vitro release study was also carried out in $\mathrm{pH} 6.8$, phosphate buffer and $0.1 \mathrm{~N}$ HCL.

\subsubsection{In-Vivo taste and sensory evaluation of roughness}

Tablet of the selected batch on the basis of disintegration time was used for in-vivo taste and sensory evaluation. Taste evaluation was done using the time intensity method on panel of 6 healthy human volunteers. One FDT was held in mouth until complete disintegration and then spat out. Bitterness was recorded immediately and at several time interval for $15 \mathrm{~min}$ according to bitterness intensity scale from $0-3$ where 0.0 .5 , 1, 2, 3 indicate no, threshold, slight, moderate and strong bitterness respectively.

\section{6}

\section{Stability study}

According to ICH guidelines, an accelerated stability study has to be carried out on the pharmaceutical dosage form at $40 \pm 2^{\circ} \mathrm{C} / 75 \pm 5 \% \mathrm{RH}$. During the present study, developed fast disintegrating tablet was subjected to accelerated stability study. The tablets were placed in stability chamber at $40^{\circ} \mathrm{C} / 75 \% \mathrm{RH}$ for three months. Three tablets were withdrawn at end of first, second and third month. After withdrawl, the tablet were crushed and quantity of powder equivalent to $10 \mathrm{mg}$ of PMZ HCL was weighed and transferred to $25 \mathrm{ml}$ volumetric flask containing about $10 \mathrm{ml} 0.1 \mathrm{~N} \mathrm{HCL}$, ultrasonicated for $10 \mathrm{~min}$ and then volume was made up to $25 \mathrm{ml}$ with 
$0.1 \mathrm{~N}$ HCL. The solution was filtered using whatman filter paper No. 41. From the filterate $0.5 \mathrm{ml}$ aliquot was withdrawn and diluted with $0.1 \mathrm{~N}$ HCL to give a concentration of $20 \mu \mathrm{g} / \mathrm{ml}$.

\section{RESULT AND DISCUSSION}

4.1 Drug excipient compatability study by FT-IR

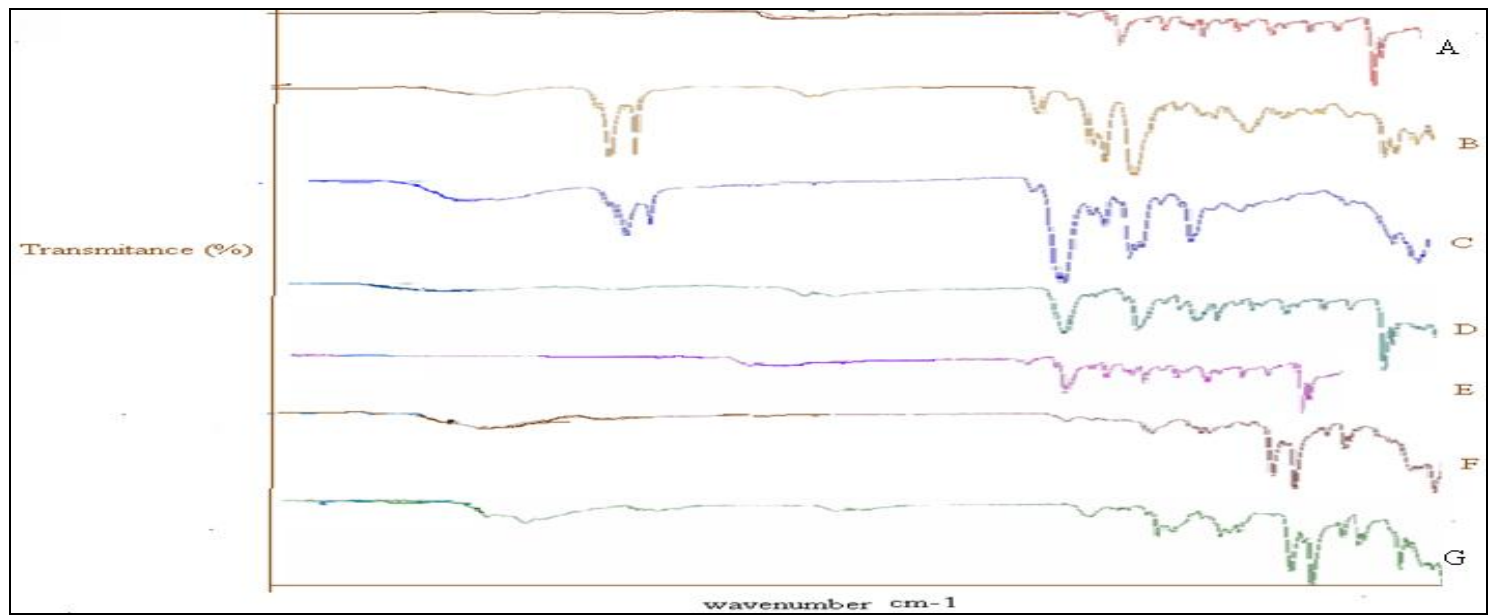

Fig. 1: A)- PMZ HCL, B)- PMZ HCL, Eurdagit E100, mg-stearate, C) - microsphere, crosspovidone, camphor, D) - PMZ HCL, Crosspovidone, E) -PMZ HCL, Camphor, F)- PMZ HCL, SSG, G)- Crushed tablet

FT-IR studies are carried out to investigate if there is any chemical interaction between polymer, added excipients and PMZ HCL in the formulated product, the FT-IR of pure drug of PMZ HCL (A), PMZ HCL+EudragitE100+Mgsterrate(microsphere)(B),Microsphere+crosspovidone+camphor(C),Drug+crosspov idone(D), Drug+ camphor (E), crushed tablet (G) were recorded. The IR spectrum of Promethazine Hcl, Eudragit E 100 an excipients showed characteristic peaks at $1651.36 \mathrm{~cm}^{-1}(\mathrm{C}-\mathrm{C}$ streching $), 1255 \mathrm{~cm}^{-1}(\mathrm{O}-\mathrm{H}$ streching), $1484 \mathrm{~cm}^{-1}\left(\mathrm{CH}_{3}\right.$ Streching), $931 \mathrm{~cm}^{-1}$ (C-O Streching), $1651.36 \mathrm{~cm}^{-1}$ (C=O Streching), $1454 \mathrm{~cm}^{-1}$ ( $\mathrm{C}-\mathrm{H}$ bending). It was observed however, that the entire characteristic peak observed for both pure drug and excipients remained unchanged, and no significant shift or reduction in the intensity of peak of PMZ HCL. FT-IR spectroscopic studies indicate that drug is compatible with polymer.

\subsection{Differential scanning colorimetry study:}

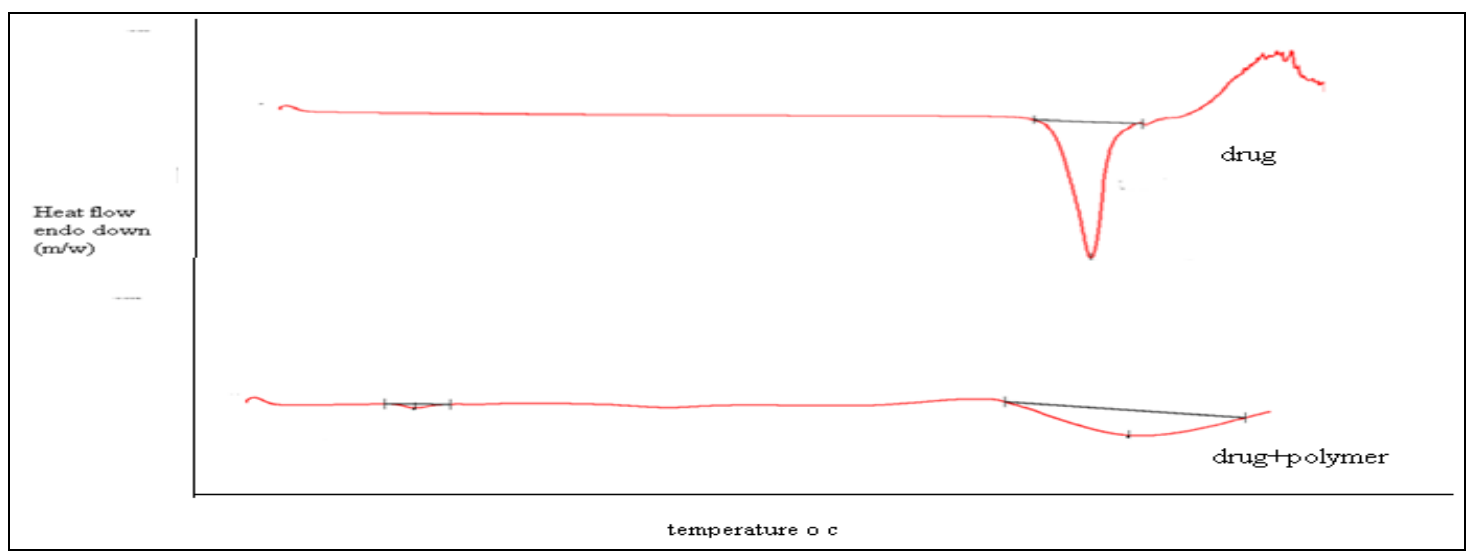

Fig. 2: DSC of Drug (PMZ HCL), PMZ HCL+ Euragit E 100

In order to check chemical interaction between drug and polymer, thermal analysis was carried out by using DSC. The melting point of drug was confirmed from the endothermic peak of Promethazine Hcl at $236.38^{\circ} \mathrm{C}$ in DSC analysis. DSC thermograms of promethazine $\mathrm{Hcl}$, Promethazine Hcl+ Eudragit E100 showed that there were no changes in the endotherms (Fig. 2). The drug exhibited a small melting endotherm in the drug polymer mixture. These slight changes in the melting endotherm of the drug may be attributed to the mixing 
process, which lowers the purity of each component in the mixture, thus resulting in slightly broader and lower melting points, but not truly representing any incompatibility.

\subsection{Powder X-RD study}

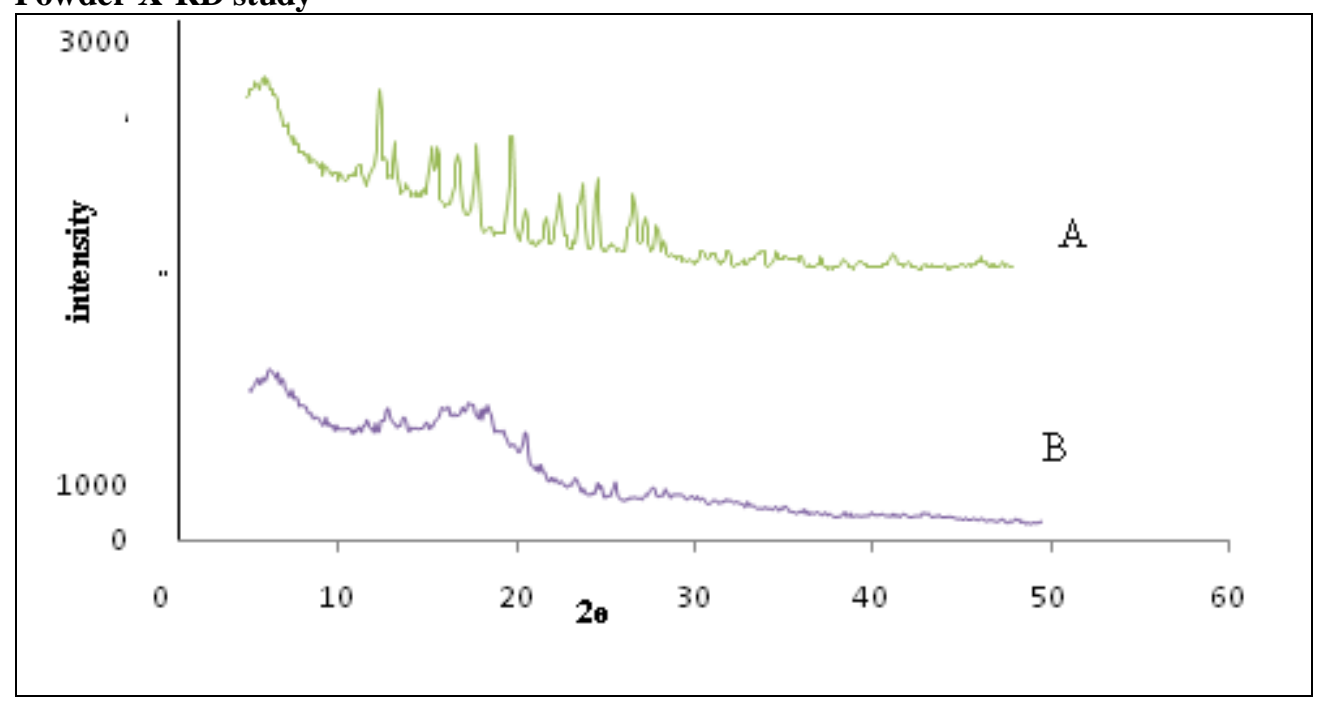

Fig. 3: X-RD study of A- Pure drug, B-microsphere

$\mathrm{X}-\mathrm{RD}$ study is carried out on the drug promethazine $\mathrm{Hcl}$ and microsphere. In Fig. 3, (A) shows sharp peak which indicate the crystalline nature of drug, $\mathrm{X}-\mathrm{RD}$ of microsphere (B) is carried out shows supression of peak which indicate crystalline form of drug is converted to amorphous form.

\section{Evaluation of microsphere}

Table no. 5 Tap density, bulk density, hausners ratio, angle of repose is measured.

\begin{tabular}{|c|c|c|c|c|c|}
\hline $\begin{array}{c}\text { Batch } \\
\text { code }\end{array}$ & Bulk density & $\begin{array}{c}\text { Tapped } \\
\text { density }\end{array}$ & $\begin{array}{c}\text { Angle of } \\
\text { repose (ө) }\end{array}$ & $\begin{array}{c}\text { Carrs index(or) } \\
\text { \% } \\
\text { compressibility }\end{array}$ & $\begin{array}{c}\text { Hausners } \\
\text { ratio }\end{array}$ \\
\hline $\mathrm{F}_{1}$ & $0.412 \pm$ & $0.433 \pm$ & $25.57 \pm$ & $5.109 \pm$ & $1.052 \pm$ \\
& 0.01 & 0.01 & 0.01 & 0.02 & 0.04 \\
\hline $\mathrm{F}_{2}$ & $0.430 \pm$ & $0.457 \pm$ & $23.18 \pm$ & $6.295 \pm$ & $1.063 \pm$ \\
& 0.02 & 0.03 & 0.03 & 0.01 & 0.01 \\
\hline $\mathrm{F}_{3}$ & $0.424 \pm$ & $0.447 \pm$ & $26.57 \pm$ & $5.438 \pm$ & $1.054 \pm$ \\
& 0.02 & 0.01 & 0.04 & 0.03 & 0.01 \\
\hline $\mathrm{F}_{4}$ & $0.429 \pm$ & $0.443 \pm$ & $25.46 \pm$ & $5.741 \pm$ & $1.057 \pm$ \\
& 0.01 & 0.02 & 0.01 & 0.02 & 0.03 \\
\hline $\mathrm{F}_{5}$ & $0.416 \pm$ & $0.451 \pm$ & $28.82 \pm$ & $5.142 \pm$ & $1.052 \pm$ \\
& 0.04 & 0.04 & 0.02 & 0.03 & 0.01 \\
\hline $\mathrm{F}_{6}$ & $0.422 \pm$ & $0.438 \pm$ & $25.41 \pm$ & $5.301 \pm$ & $1.053 \pm$ \\
& 0.1 & 0.03 & 0.05 & 0.01 & 0.01 \\
\hline $\mathrm{F}_{7}$ & $0.426 \pm$ & $0.444 \pm$ & $30.97 \pm$ & $5.225 \pm$ & $1.052 \pm$ \\
& 0.01 & 0.01 & 0.01 & 0.03 & 0.02 \\
\hline $\mathrm{F}_{8}$ & $0.430 \pm$ & $0.448 \pm$ & $28.58 \pm$ & $5.176 \pm$ & $1.051 \pm$ \\
& 0.02 & 0.02 & 0.02 & 0.02 & 0.01 \\
\hline
\end{tabular}

$(\mathrm{n}=3), \mathrm{SD}( \pm)=$ Standard deviation

\subsubsection{Particle size}

Size distribution and average particle size was calculated using optical microscope fitted with eye piece micrometer which is calibrated by stage micrometer. A small size is desired to avoid gritty feeling in the mouth. 


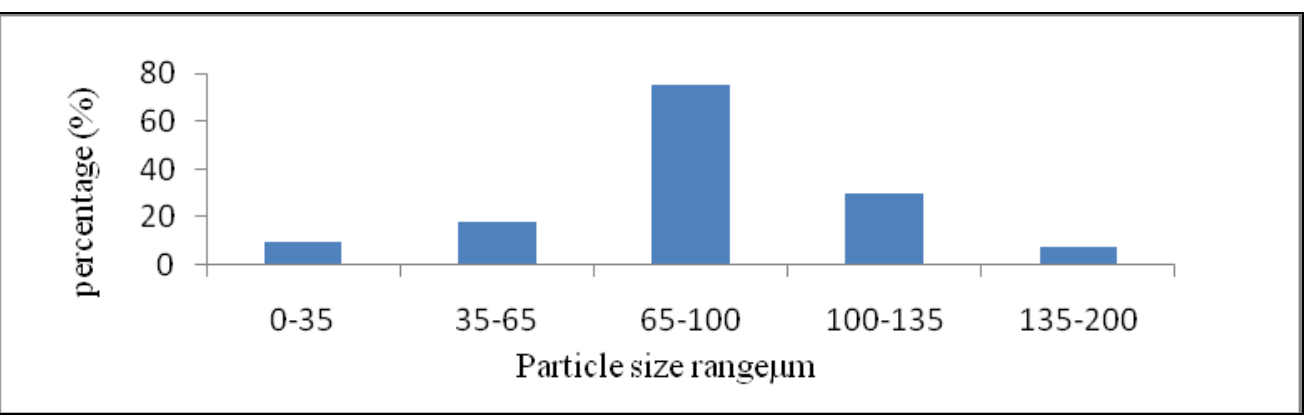

Fig. 4: Graph showing particle size distribution of microspheres

\subsubsection{Morphology}

It was observed from the photomicrographs (Fig. 5) that the microspheres were spherical in shape and their surface was free of any adhering drug which might otherwise impart a bitter taste.

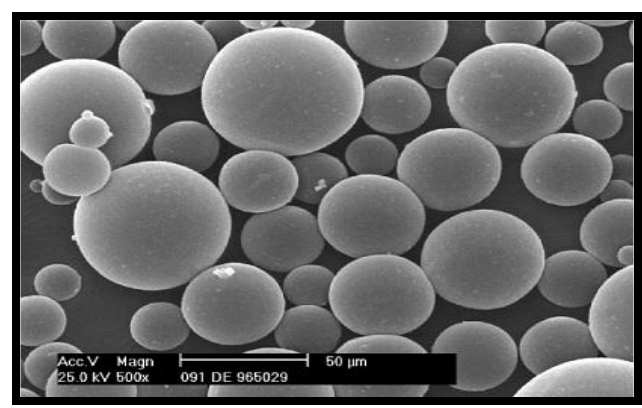

Fig. 5: Scanning electron photomicrograph of PMZ HCL

\subsubsection{Entrapment efficiency}

A small quantity of microspheres was crushed in a glass mortar and to $10 \mathrm{mg}$ of an accurately weighed sample of this powdered mass, was added to $\mathrm{pH} 6.8$ phosphate buffer and analyzed spectrophotometrically at $\lambda \max 249 \mathrm{~nm}$ using buffer as blank. The entrapment efficiency of various samples was calculated using the following equation,
Entrapment $\quad=$
Weight of incorporated drug (mg)
$\mathrm{x} 100$
Efficiency $\quad$ Weight of drug used for microsphere preparation $(\mathrm{mg})$

Table no. 6 Effect of varying polymer concentration on drug entrapment efficiency and taste perception of microspheres.

\begin{tabular}{|c|c|c|}
\hline $\mathbf{W}_{\text {Drug }}: \mathbf{W}_{\text {Polymer }}$ & Entrapment efficiency & Taste perception \\
\hline $1: 1$ & $39.08 \%$ & Bitter \\
\hline $1: 2$ & $51 \%$ & Bitter \\
\hline $1: 3$ & $78.08 \%$ & Bitter \\
\hline $1: 4^{*}$ & $85.41 \%$ & Tasteless \\
\hline
\end{tabular}

*Selected as the optimized taste-masked microsphere composition w.r.t. entrapment efficiency, particle size and taste masking.

\subsubsection{Taste of microsphere}

In-Vivo taste evaluation:-

Table no.7 Degree of bitterness after time

\begin{tabular}{|c|c|c|c|c|c|c|}
\hline $\begin{array}{c}\text { Formulation of } \\
\text { tablet }\end{array}$ & 10s & 1min & 2min & 5min & 10min & 15min \\
\hline Pure drug & 3 & 3 & 3 & 3 & 3 & 3 \\
\hline $\begin{array}{c}\text { Drug polymer } \\
\text { complex (1:4) }\end{array}$ & 0 & 0 & 1 & 0 & 0 & 0 \\
\hline
\end{tabular}


Several batches of microspheres were prepared by varying the drug-polymer ratio, keeping all other formulation factors constant. It was found that as the polymer content increases the drug entrapment efficiency increases and the taste perception changes from bitter to tasteless. A drug: polymer ratio of 1: 4 produced tasteless microspheres with the highest entrapment efficiency of $85.41 \%$, so this was used for further studies (Table no, 6 and 7)

\subsection{Evaluation of taste masked FDTs}

Table no. 8 Evaluation of tablet for hardness, friability, disintegration time

\begin{tabular}{|c|c|c|c|c|c|c|}
\hline $\begin{array}{l}\text { Bath } \\
\text { code }\end{array}$ & $\begin{array}{l}\text { Weight } \\
(\mathrm{mg}) \pm \mathrm{SD}\end{array}$ & $\begin{array}{l}\text { Hardness } \\
\left(\mathrm{Kg} / \mathrm{cm}^{2}\right) \pm \mathrm{SD}\end{array}$ & $\begin{array}{l}\text { Wetting } \\
\text { time(sec) } \quad \pm \\
\text { SD }\end{array}$ & $\begin{array}{l}\text { Friability (\%) } \\
\pm \text { SD }\end{array}$ & $\begin{array}{l}\text { Dispersion time } \\
\text { (sec) } \pm \text { SD }\end{array}$ & $\begin{array}{l}\text { Disintegr- } \\
\text { ation time } \\
(\mathrm{sec}) \pm \mathrm{SD}\end{array}$ \\
\hline $\mathrm{F}_{1}$ & $\begin{array}{c}145.6 \pm \\
0.02\end{array}$ & $\begin{array}{l}2.5 \pm \\
0.02\end{array}$ & $\begin{array}{l}54 \pm \\
0.04\end{array}$ & $\begin{array}{c}0.324 \pm \\
0.02\end{array}$ & $\begin{array}{l}58 \pm \\
0.01\end{array}$ & $\begin{array}{l}52 \pm \\
0.02\end{array}$ \\
\hline $\mathrm{F}_{2}$ & $\begin{array}{l}148 \pm \\
0.01\end{array}$ & $\begin{array}{l}2.4 \pm \\
0.03\end{array}$ & $\begin{array}{l}44 \pm \\
0.03\end{array}$ & $\begin{array}{c}0.432 \pm \\
0.03\end{array}$ & $\begin{array}{l}42 \pm \\
0.03\end{array}$ & $\begin{array}{l}36 \pm \\
0.12\end{array}$ \\
\hline $\mathrm{F}_{3}$ & $\begin{array}{c}154.4 \pm \\
0.04\end{array}$ & $\begin{array}{l}2.6 \pm \\
0.02\end{array}$ & $\begin{array}{l}29 \pm \\
0.03\end{array}$ & $\begin{array}{c}0.264 \pm \\
0.01\end{array}$ & $\begin{array}{l}28 \pm \\
0.01\end{array}$ & $\begin{array}{l}24 \pm \\
0.05\end{array}$ \\
\hline $\mathrm{F}_{4}$ & $\begin{array}{c}143.5 \pm \\
0.02\end{array}$ & $\begin{array}{l}2.4 \pm \\
0.03\end{array}$ & $\begin{array}{l}16 \pm \\
0.02\end{array}$ & $\begin{array}{c}0.342 \pm \\
0.02\end{array}$ & $\begin{array}{l}14 \pm \\
0.02\end{array}$ & $\begin{array}{l}15 \pm \\
0.14\end{array}$ \\
\hline $\mathrm{F}_{5}$ & $\begin{array}{c}145.2 \pm \\
0.01\end{array}$ & $\begin{array}{l}2.8 \pm \\
0.01\end{array}$ & $\begin{array}{l}56 \pm \\
0.01\end{array}$ & $\begin{array}{c}0.322 \pm \\
0.03\end{array}$ & $\begin{array}{l}54 \pm \\
0.01\end{array}$ & $\begin{array}{l}54 \pm \\
0.05\end{array}$ \\
\hline $\mathrm{F}_{6}$ & $\begin{array}{c}152.4 \pm \\
0.04\end{array}$ & $\begin{array}{l}2.2 \pm \\
0.03\end{array}$ & $\begin{array}{l}44 \pm \\
0.03\end{array}$ & $\begin{array}{c}0.431 \pm \\
0.02\end{array}$ & $\begin{array}{l}41 \pm \\
0.04\end{array}$ & $\begin{array}{l}34 \pm \\
0.17\end{array}$ \\
\hline $\mathrm{F}_{7}$ & $\begin{array}{c}146.5 \pm \\
0.03\end{array}$ & $\begin{array}{l}2.6 \pm \\
0.02\end{array}$ & $\begin{array}{l}27 \pm \\
0.01\end{array}$ & $\begin{array}{c}0.212 \pm \\
0.01\end{array}$ & $\begin{array}{l}24 \pm \\
0.02\end{array}$ & $\begin{array}{l}27 \pm \\
0.10\end{array}$ \\
\hline $\mathrm{F}_{8}$ & $\begin{array}{c}146.2 \pm \\
0.02\end{array}$ & $\begin{array}{l}2.5 \pm \\
0.04\end{array}$ & $\begin{array}{c}20 \pm \\
0.2\end{array}$ & $\begin{array}{c}0.342 \pm \\
0.03\end{array}$ & $\begin{array}{l}18 \pm \\
0.02\end{array}$ & $\begin{array}{l}17 \pm \\
0.08\end{array}$ \\
\hline
\end{tabular}

$(\mathrm{n}=3), \mathrm{SD}( \pm)=$ Standard deviation

The result of angle repose $(<30)$ indicate good flow properties of immediate release granules. This was further supported by lower Carr's index value. Carr's index value up to $12 \%$ resulted in excellent flow properties. Thus all the formulation was found to exhibit good to excellent flow properties.

\subsubsection{Dissolution study of taste masked tablets}

Dissolution studies were carried as per U.S.P 2010 in $900 \mathrm{ml} 0.1 \mathrm{~N}$ HCL and pH 6.8 phosphate buffer at $100 \mathrm{rpm} . \%$ release was calculated using calibration curve in $\mathrm{pH} 6.8$ phosphate buffer with equation $\mathrm{Y}=0.111 \mathrm{x}$ an correlation coefficient $\left(\mathrm{r}^{2}\right) 0.998$ and $0.1 \mathrm{~N}$ HCL with equation $\mathrm{Y}=0.118 \mathrm{x}$ an correlation coefficient $\left(r^{2}\right) 0.998$

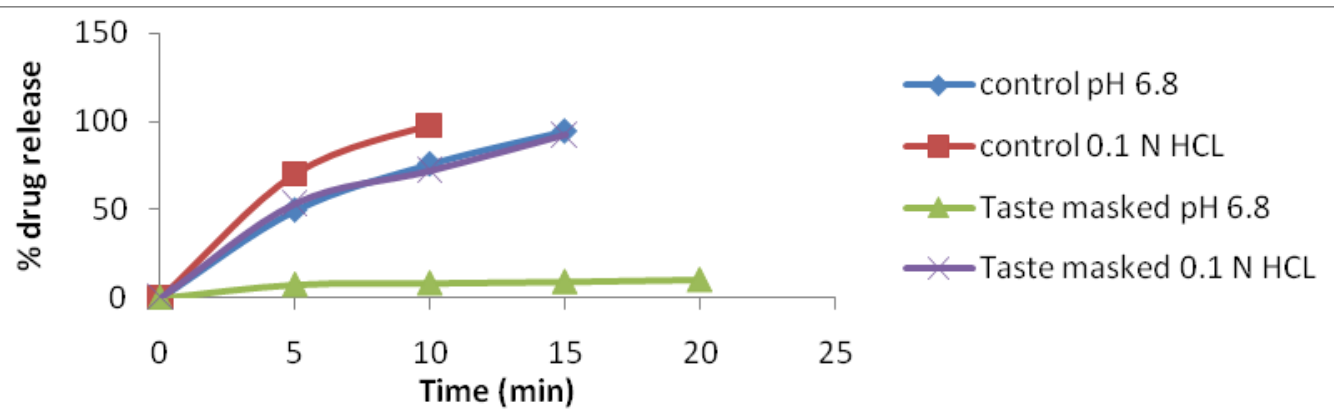

Fig. 6: Plot showing the percentage cumulative release of promethazine hydrochloride from FDTs of pure drug (control) and taste-masked microspheres at $\mathrm{pH} 6.8$ and $\mathrm{pH} 0.1 \mathrm{~N} \mathrm{HCL}$

The dissolution profiles of control (pure drug) and taste-masked FDTs of PMZ HCL, carried out at two different $\mathrm{pH}$ values. By comparing the release profiles of taste masked and control (pure drug) FDTs of promethazine hydrochloride at $\mathrm{pH} 6.8$, it was found that there is a marked difference in the dissolution profiles of tablet whose taste masked and that of control (pure drug). As much as $94.12 \%$ of the drug is released from the control (pure drug) in 15 min while only about $12.19 \%$ is released from the FDTs of microspheres. These results confirm the pH-sensitive nature of Eudragit E100 which does not dissolve at a pH above 5. This also suggests that sufficient taste-masking was achieved and that the bitter taste of the drug will not be perceived while the tablet is in the mouth after oral administration. 
As Eudragit E100 is soluble at $\mathrm{pH}$ values below $5, \mathrm{pH} 0.1 \mathrm{~N}$ hydrochloric acid buffer simulating gastric fluid was chosen as the second medium. It was found that about $97.8 \%$ of promethazine Hcl was released from control (pure drug) and 92.3\% was released after $15 \mathrm{~min}$ of dissolution from the taste-masked FDTs of microsphere. This, therefore, suggests that the drug will easily be released from the microspheres in the acidic $\mathrm{pH}$ of the stomach. Furthermore, the release profile of the drug from the FDTs of taste masked microspheres and control (pure drug) was comparable and super imposable at $\mathrm{pH} 0.1 \mathrm{~N} \mathrm{HCL}$ indicating that the drug will be released at approximately the same rate and to the same extent in the stomach. This shows that taste masking the drug with the $\mathrm{pH}$-sensitive polymer will not affect the release of the drug in the stomach The hardness and friability of the of the batch $\left(\mathrm{F}_{4}\right)$ of promethazine hydrochloride FDTs (Table no.8) were found to be satisfactory and within the limits specified for fast disintegrating tablets. The wetting time was found to be $16 \pm 0.02 \mathrm{~s}$ and the dispersion time was found to be $14 \pm 0.02$. The disintegration time of the FDTs in $900 \mathrm{ml} \mathrm{pH} 6.8$ phosphate buffer using USP disintegration apparatus was found to be $15 \pm 0.14$ within the limits reported for fast disintegrating tablets (Table no.8), showing that fast disintegration had been successfully achieved.

\subsubsection{In- Vivo taste and sensory evaluation}

From the above studies batch $\mathrm{F}_{4}$ was selected on the basis of disintegration time of tablet as final formulations that contain $10 \%$ of superdisintegrant and it was further studied for the comparative in-vivo and sensory evaluation. Taste evaluation was done using time intensity method on a panel of 6 healthy volunteers from whom informed consent was first obtained. Bitterness was recorded immediately and at several intervals for $15 \mathrm{~min}$ according to bitterness intensity scale from 0-3 where 0,1,2,3 indicate no, slight, moderate, and strong bitterness.

Table no. 9 Degree of bitterness of taste masked tablet after time

\begin{tabular}{|c|c|c|c|c|c|c|}
\hline $\begin{array}{c}\text { Formulation of } \\
\text { tablet }\end{array}$ & $\mathbf{1 0 s}$ & $\mathbf{1 m i n}$ & $\mathbf{2 m i n}$ & $\mathbf{5 m i n}$ & $\mathbf{1 0 m i n}$ & $\mathbf{1 5 m i n}$ \\
\hline Pure drug & 3 & 3 & 3 & 3 & 3 & 3 \\
\hline $\begin{array}{c}\text { Drug polymer } \\
\text { complex (1:4) }\end{array}$ & 0 & 0 & 1 & 0 & 0 & 0 \\
\hline
\end{tabular}

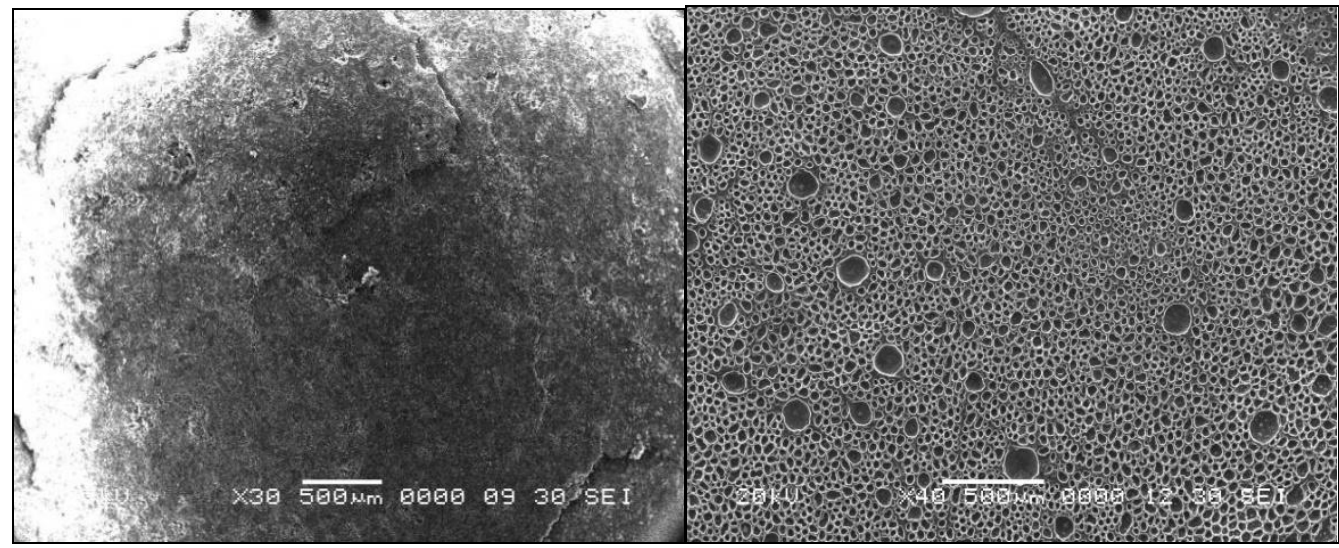

A) Before sublimation

B) After sublimation

Fig. 7: represent the images of tablet before and after sublimation

\subsection{Stability studies}

Stability of the $\mathrm{F}_{4}$ batch was checked after 1, 2, 3 months.

Table no. 10 Result of stability study of $F_{4}$ batch

\begin{tabular}{|c|c|c|}
\hline Interval & Disintegration time(sec) & Dissolution(\% drug release) \\
\hline $1 \mathrm{mth}$ & $18 \mathrm{sec}$ & $94.6 \%$ \\
\hline $2 \mathrm{mth}$ & $14 \mathrm{sec}$ & $92.8 \%$ \\
\hline $3 \mathrm{mth}$ & $16 \mathrm{sec}$ & $95.8 \%$ \\
\hline
\end{tabular}


Stability study of fast disintegrating tablet was checked at $40 \pm 2^{0} / 75 \pm 5 \%$ RH. Analysis was done after 1,2 and 3 months for disintegration and dissolution. There was no effect seen on the dissolution and disintegration time and no change on the hardness and friability of tablet was seen, Hence tablet was found to be stable.

\section{CONCLUSION}

In conclusion, the objective of formulating fast disintegrating tablets of Promethazine Hcl using the technique of sublimation and super-disintegrant addition has been successfully achieved. Also, as a prerequisite, effective inhibition of the bitter taste of PMZ HCL was achieved by preparing taste-masked microspheres using a $\mathrm{pH}$-sensitive polymer which does not dissolve at salivary $\mathrm{pH}$. The tablets with an acceptable taste and rapid disintegration in the mouth will be useful practical for both geriatric and pediatric patients and can be successfully produced commercially after a full stability evaluation.

\section{REFERENCES}

[1] Jaysukh JH, Dhaval AR, Kantilal RV, Orally disintegrating tablet: A Review, Tropical journal of pharmaceutical research, 2(4), $2009,161-172$

[2] Y. Fu, S. Yang, S.H. Jeong, Orally fast disintegrating tablets: developments, technologies, taste-masking and clinical studies, Crit. Rev. Ther. Drug Carrier Syst, 2(1), 2004, 433-476.

[3] Lokesha P, Kunchu K, Tamizh Mani T, Fast disintegrationg tablet: An overview of formulation, technology and evaluation, Research Journal of Pharmaceutical, Biological and Chemical Sciences, 1(2), 2011, 589-601.

[4] Shishu A, Bhatti T, Singh, Preparation of tablets rapidly disintegrating in saliva containing bitter taste-masked granules by sublimation method, Ind. J. Pharm. Sci, 4(9), 2007, 80-84.

[5] A. Wade, P. J. Weller, Polymethacrylates in Handbook of Pharmaceutical Excipients, (The Pharmaceutical Press, London, 1994) 362-366.

[6] Kamalpreet, Varun RK, Development of taste-masked fast disintegrating tablets of tinidazole, Asian Journal of Pharmaceutical Sciences, 1(4), 39-45.

[7] Vineet B, Mayank B, Sharma PK, Formulation and Evaluation of Fast Dissolving Tablets of Amlodipine Besylate Using Different Super Disintegrants and Camphor as Sublimating Agent, American-Eurasian Journal of Scientific Research, 2(5), 2010, 264-269.

[8] Rajkumar G, Satyendra SB, Ashish P, Kshamashil S, Gourav T, Rituraj S, A review on formulation and evaluation of orodispersible tablets, World Journal of Pharmaceutical Research, 2(3), 2012, 576-590.

[9] Sehgal P, Gupta R, Singh U, Chaturvedi A, Gulati A, Sharma M, Fast dissolving tablets: A New Venture in Drug Delivery, American Journal of Pharmatech Research, 1(4), 2012, 253-279.

[10] Anand A, Suresh VK, Someshwara RB, Ramesh B, Pramod P, Taste masking of Dicyclomine hydrochloride by polymer carrier system and formulation of oral disintegrating tablets, Asian Journal of Pharmaceutical and Clinical Research, 2(4), 2011, 35-40.

[11] Karan M, Gurpreet A, Inderbir S, Taste Masked Microspheres of Ofloxacin: Formulation and Evaluation of Orodispersible Tablets, Sci Pharm, 3(9), 2011, 653-672.

[12] Shukla D, Chakraborty S, Singh S, Mishra B, Mouth Dissolving tablet: An Overview of evaluation techniques, Sci Pharm, 3(2), 2009, 327-341.

[13] Kaushik D, Mouth dissolving tablet: A Review, Indian Drug, 3(1), 2004, 187-193

[14] Irwin, CJ, Method of producing tablets with improved dissolution properties, European patent, 2002, 136-767.

[15] Yagmur B, Tansel C, Formulation and evaluation of oral fast disintegrating tablets, Marmara pharmaceutical Journals, 1(4), 2012, $77-81$. 